Check for updates

Cite this: RSC Adv., 2021, 11, 16179

\title{
Bioactive natural products from marine sponges belonging to family Hymedesmiidae $\uparrow$
}

\author{
Asmaa Abo Elgoud Said, ${ }^{a}$ Basma Khalaf Mahmoud, ${ }^{a}$ Eman Zekry Attia, ${ }^{a}$ \\ Usama Ramadan Abdelmohsen (D)*ab and Mostafa Ahmed Fouad ${ }^{\star a}$
}

Natural products of marine origin exhibit extensive biological activities, and display a vital role in the exploration of new compounds for drug development. Marine sponges have been reported at the top with respect to the discovery of biologically active metabolites that have potential pharmaceutical applications. The family Hymedesmiidae belonging to the Demospongiae class includes ten accepted genera, of which four genera were explored for their bioactive metabolites, namely Phorbas, Hamigera, Hemimycale, and Kirkpatrickia. Genus Phorbas has received more attention due to the isolation of various classes of compounds with unique structures mainly diterpenes, alkaloids, sesterterpenes, and steroids that exhibited diverse biological activities including: antiviral, antimicrobial, and antiinflammatory, whereas anticancer compounds predominated. This review focuses on the isolated secondary metabolites from family Hymedesmiidae with their biological potential and covers the

literature from 1989 to 2020.

Received 11th January 2021

Accepted 26th March 2021

DOI: $10.1039 / \mathrm{d} 1 \mathrm{ra00228g}$

rsc.li/rsc-advances

\section{Introduction}

Marine sponges are sessile and soft-bodied organisms collecting small particles of food from seawater. They produce defensive metabolites to protect themselves from predators and fouling organisms that tend to set onto their outer surfaces. These sessile animals are a precious resource for an enormous diversity of bioactive metabolites that have been reported over the past 50 years. There are more than 8000 known species of sponges, distributed widely in the sea and freshwater environments. ${ }^{1}$ As a consequence of diverse chemical and physical environments, nearly every cluster of marine sponge affords a variety of bioactive compounds with exclusive structural features. ${ }^{2}$ On the other hand, natural products isolated from marine sponges can be a promising way to obtain new therapeutic strategies for the treatment of most diseases. ${ }^{3}$

Family Hymedesmiidae harbors the largest number of species within the class Demospongiae. This family contains 10 accepted genera, including Acanthancora, Phorbas, Hamigera, Hemimycale, Pseudohalichondria, Plocamionida, Spanioplon, Myxodoryx, Hymedesmia and Kirkpatrickia. ${ }^{4,5}$ There are different classes of biologically active compounds isolated from this family such as alkaloids, diterpenes, sesterterpenes, steroids,

${ }^{a}$ Department of Pharmacognosy, Faculty of Pharmacy, Minia University, 61519 Minia, Egypt.E-mail: usama.ramadan@mu.edu.eg; m_fouad2000@yahoo.com; Fax:+2-862369075; Tel: $+2-86-2347759$

${ }^{b}$ Department of Pharmacognosy, Faculty of Pharmacy, Deraya University, Universities Zone, 61111 New Minia City, Egypt

$\dagger$ Electronic supplementary information (ESI) available. See DOI: $10.1039 / \mathrm{d} 1 \mathrm{ra} 00228 \mathrm{~g}$ and macrolides, of which the majority was afforded from genus Phorbas (Fig. 1, Table S1 $\dagger$ ). The isolated secondary metabolites exhibited variety of potential pharmacological activities such as anti-tumor, anti-inflammatory, antimicrobial, hypoglycemic, antioxidant, and anti-melanogenic.

Genus Phorbas received more attention among all genera due to its isolated secondary metabolites that exhibit cytotoxic activities on various cell lines such as hepatocellular carcinoma, leukemia, colon cancer, lung cancer, and breast cancer. One hundred and eighty one compounds were isolated from this family, from which one hundred and thirteen were tested for their pharmacological activities and the majority of these metabolites were isolated in the period from 2006 to 2015

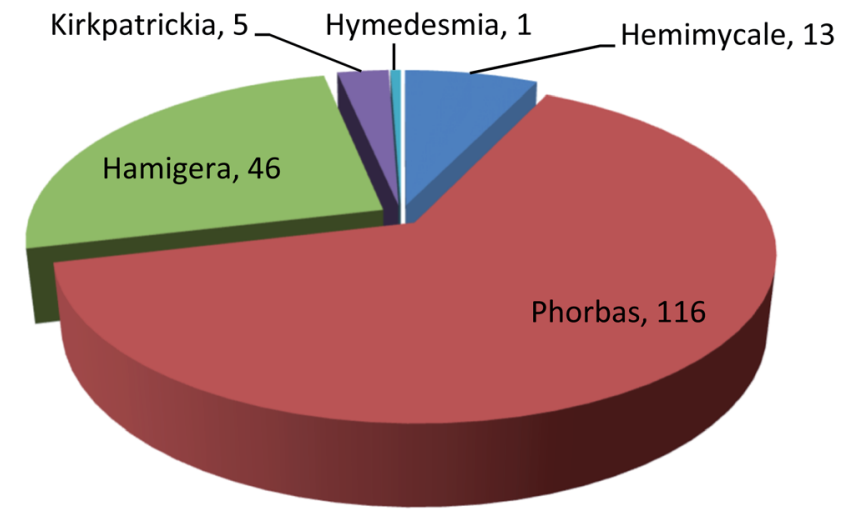

Fig. 1 Number of compounds isolated from different genera of family Hymedesmiidae. 


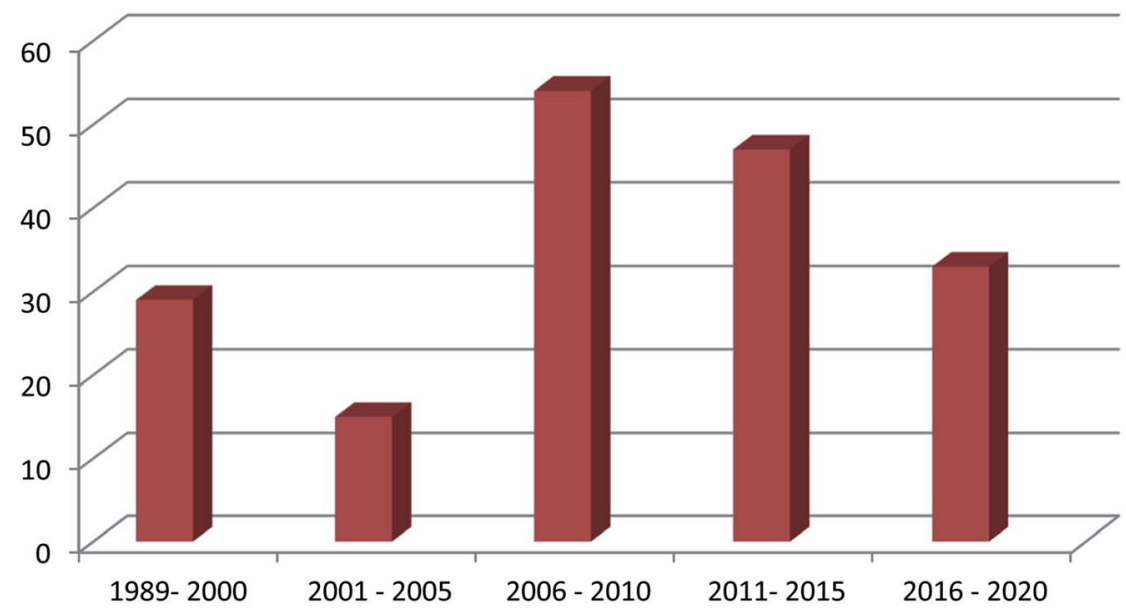

Fig. 2 Number of metabolites isolated from family Hymedesmiidae over the period 1989-2020.

(Fig. 2). It is worth mentioning that phorbaketal A, one of the highlighted isolated compounds, was found to provide a new strategy for the treatment of common diseases as osteoporosis and obesity. This review covers the literature on only the isolated bioactive natural products and thus, their pharmacological activities, from family Hymedesmiidae from 1989 until December 2020. However, the non-bioactive isolated compounds were mentioned in the ESI. $\dagger$

\section{Isolated bioactive compounds from family Hymedesmiidae}

\subsection{Genus Phorbas Duchassaing \& Michelotti, 1864}

Genus Phorbas had been investigated for several years, resulting in the isolation of diverse pharmacologically active secondary metabolites including; alkaloids, terpenoids and steroids. Alkaloids are the first class of compounds isolated from genus Phorbas, have an unusual nucleus such as, anchinopeptolides, zarzissine, and phorbatopsins and exhibit remarkable biological activities. Anchinopeptolides are small group of peptide alkaloids isolated from the Mediterranean marine sponge Phorbas tenacior (previously Anchinoe tenacior). ${ }^{6}$ Anchinopeptolides include, anchinopeptolide A (1), B (2), C (3), and D (4) (Fig. 3). ${ }^{7,8}$ Biosynthetically, these four alkaloids were expected to be originated from the dimerization of modified tripeptides that derived from arginine, glycine or alanine together with hydroxystyrylamide, which probably formed from tyrosine amino acid. ${ }^{9}$ Additionally, anchinopeptolides (B-D) at concentration of $5 \mu \mathrm{g} \mathrm{mL} \mathrm{mL}^{-1}$ exerted significantly displacement of specific ligands from their receptors as neuropeptide Y receptor

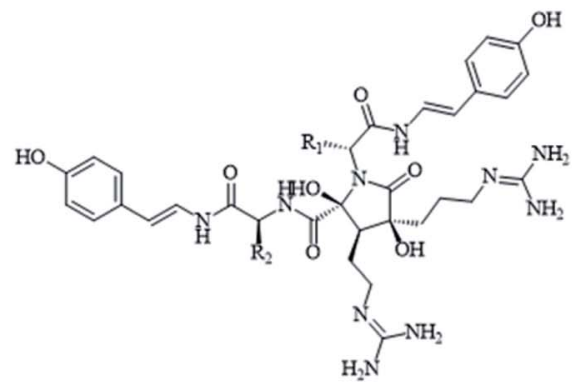

$$
\begin{aligned}
& \text { 1: } \mathrm{R}_{1}=\mathrm{R}_{2}=\mathrm{Me} \\
& \text { 2: } \mathrm{R}_{1}=\mathrm{Me}, \mathrm{R}_{2}=\mathrm{H} \\
& \text { 3: } \mathrm{R}_{1}=\mathrm{H}, \mathrm{R}_{2}=\mathrm{Me} \\
& \text { 4: } \mathrm{R}_{1}=\mathrm{R}_{2}=\mathrm{H}
\end{aligned}
$$<smiles>Nc1nc2cnncc2[nH]1</smiles><smiles>[R16]C(c1ccc(O)cc1)C1([R1])NC(=N)N=C1O</smiles><smiles>N=C1N=C(O)/C(=C\c2ccc(O)cc2)N1</smiles>

6

Fig. 3 Structure of compounds 1-8. 


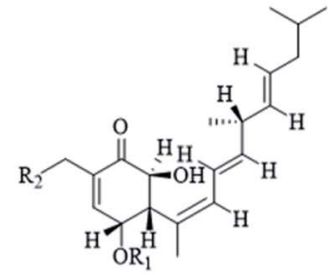

9: $\mathrm{R}_{1}=\mathrm{H}_{2} \mathrm{R}_{2}=\mathrm{OH}$

$10: \mathrm{R}_{1}=\mathrm{Ac}, \mathrm{R}_{2}=\mathrm{OH}$

11: $\mathrm{R}_{1}=\mathrm{H}, \mathrm{R}_{2}=\mathrm{NHCH}_{2} \mathrm{CH}_{2} \mathrm{SO}_{3} \mathrm{H}$

14: $R_{1}=R_{2}=H$

15: $\mathrm{R}_{1}=\mathrm{Ac}, \mathrm{R}_{2}=\mathrm{H}$

16: $R_{1}=A c, R_{2}=O E t$

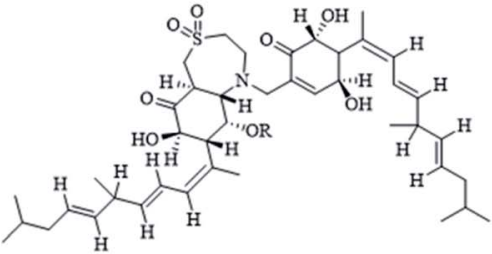

$12: \mathrm{R}=\mathrm{H}$

$13: \mathrm{R}=\mathrm{Ac}$

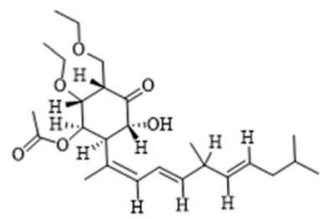

17

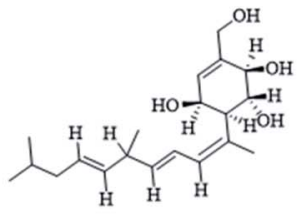

18

Fig. 4 Structure of compounds 9-18.

(57-80\%), somatoststin receptor (62-73\%), and human B2 bradykinin receptor (52-71\%). ${ }^{9}$ Anchinopeptolide A exerted weaker activity at the same concentration. ${ }^{7}$ A pyridazine derivative named zarzissine (5) (Fig. 3) was isolated from the marine sponge phorbas paupertas (Anchinooe paupertas) and showed potent cytotoxic activity against three cell lines namely, murine leukemia (P-388), human nasopharyngeal carcinoma (KB), and human lung carcinoma (NSCLC-N6), whereas the maximum cytotoxic activity was exerted against nasopharyngeal carcinoma with an $\mathrm{IC}_{50}$ value of $37.001 \mu \mathrm{M}$, besides slight lower activity against leukemia and lung carcinoma with $\mathrm{IC}_{50}$ values of 88.803 and $74.003 \mu \mathrm{M}$, respectively. ${ }^{10}$

Phorbatopsins are the latest group of alkaloids isolated from Phorbas topsenti. They are benzylidene 2-aminoimidazolones compounds, named phorbatopsin A (6), B (7), and C (8) (Fig. 3). ${ }^{11}$ Their antioxidant potential which was investigated through the oxygen radical absorbance capacity (ORAC) assay, revealed that the maximum activity exerted by phorbatopsin $\mathrm{A}$ with an ORAC value of 0.88 compared with standard antioxidant Trolox $^{\circledR}$, however phorbatopsin B and C showed ORAC value of 0.50 and 0.21 , respectively. ${ }^{12}$

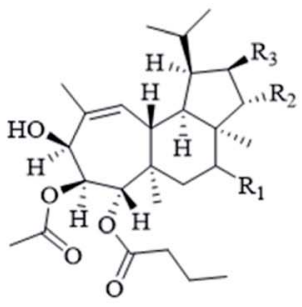

19: $\mathrm{R}_{1}=\mathrm{R}_{2}=\mathrm{OCOCH}_{2} \mathrm{CH}_{2} \mathrm{CH}_{3}, \mathrm{R}_{3}=\mathrm{OCOCH}_{2} \mathrm{CH}_{2}\left(\mathrm{CH}_{3}\right)_{2}$

20: $\mathrm{R}_{1}=\mathrm{R}_{2}=\mathrm{R}_{3}=\mathrm{OCOCH}_{2} \mathrm{CH}_{2} \mathrm{CH}_{3}$

22: $\mathrm{R}_{1}=\mathrm{R}_{3}=\mathrm{OCOCH}_{2} \mathrm{CH}_{2} \mathrm{CH}_{3}, \mathrm{R}_{2}=\mathrm{H}$

27: $\mathrm{R}_{1}=\mathrm{OCOCH}_{3}, \mathrm{R}_{2}=\mathrm{R}_{3}=\mathrm{OCOCH}_{2} \mathrm{CH}_{2} \mathrm{CH}_{3}$

29: $\mathrm{R}_{1}=\mathrm{R}_{2}=\mathrm{OCOCH}_{2} \mathrm{CH}_{2} \mathrm{CH}_{3}, \mathrm{R}_{3}=\mathrm{OCOCH}_{2} \mathrm{CH}_{2} \mathrm{CH}_{2} \mathrm{CH} 3$

31: $\mathrm{R}_{1}=\mathrm{OCOCH}_{2} \mathrm{CH}_{2}(\mathrm{CH} 3)_{2}, \mathrm{R}_{2}=\mathrm{H}, \mathrm{R}_{3}=\mathrm{OCOCH}_{2} \mathrm{CH}_{2} \mathrm{CH}_{3}$
21: $\mathrm{R}_{1}=\mathrm{R}_{3}=\mathrm{OCOCH}_{2} \mathrm{CH}_{2} \mathrm{CH}_{3}, \mathrm{R}_{2}=\mathrm{OCOCH}_{3}$

26: $\mathrm{R}_{1}=\mathrm{OCOCH}_{2} \mathrm{CH}_{3}, \mathrm{R}_{2}=\mathrm{R}_{3}=\mathrm{OCOCH}_{2} \mathrm{CH}_{2} \mathrm{CH}_{3}$

28: $\mathrm{R}_{1}=\mathrm{R}_{3}=\mathrm{OCOCH}_{2} \mathrm{CH}_{2} \mathrm{CH}_{3}, \mathrm{R}_{2}=\mathrm{OCOCH}_{2} \mathrm{CH}_{3}$

30: $\mathrm{R}_{1}=\mathrm{OCOCH}_{3}, \mathrm{R}_{2}=\mathrm{H}, \mathrm{R}_{3}=\mathrm{OCOCH}_{2} \mathrm{CH}_{2} \mathrm{CH}_{3}$

Fig. 5 Structure of compounds $19-22$ and 26-31. 


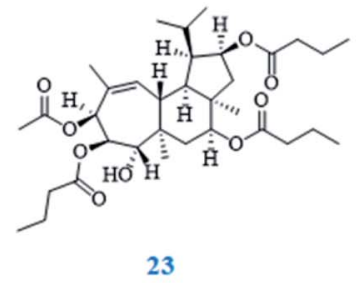

23

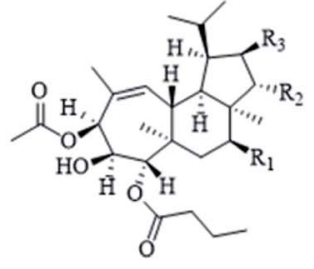

24: $\mathrm{R}_{1}=\mathrm{R}_{3}=\mathrm{OCOCH}_{2} \mathrm{CH}_{2} \mathrm{CH}_{3}, \mathrm{R}_{2}=\mathrm{H}$

25: $\mathrm{R}_{1}=\mathrm{OCOCH}_{2} \mathrm{CH}_{2} \mathrm{CH}_{3}, \mathrm{R}_{2}=\mathrm{H}, \mathrm{R}_{3}=\mathrm{OCOCH}_{3}$

32: $\mathrm{R}_{1}=\mathrm{OCOCH}_{3}, \mathrm{R}_{2}=\mathrm{H}, \mathrm{R}_{3}=\mathrm{OCOCH}_{2} \mathrm{CH}_{2} \mathrm{CH}_{3}$

33: $\mathrm{R}_{1}=\mathrm{R}_{2}=\mathrm{R}_{3}=\mathrm{OCOCH}_{2} \mathrm{CH}_{2} \mathrm{CH}_{3}$

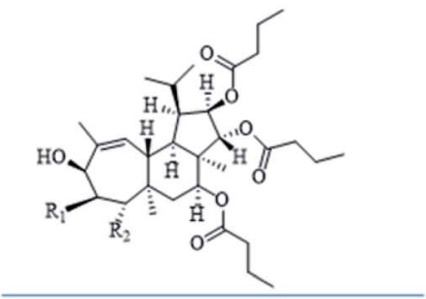

34: $\mathrm{R}_{1}=\mathrm{R}_{2}=\mathrm{OCOCH}_{3}$

35: $\mathrm{R}_{1}=\mathrm{OCOCH}_{2} \mathrm{CH}_{3}, \mathrm{R}_{2}=\mathrm{OCOCH}_{2} \mathrm{CH}_{2} \mathrm{CH}_{3}$

Fig. 6 Structure of compounds $23-25$ and $32-35$.

Bioactive terpenoidal compounds are other class of secondary metabolites isolated from Phorbas species including; diterpenes, tetraterpenes and sesterterpenes. There are two groups of diterpenoidal compounds isolated from the Australian marine sponge Phorbas sp., named phorbasins and gagunins. Phorbasins compounds include, phorbasins B-K (9-18) (Fig. 4), ${ }^{13-15}$ Moreover, phorbasins D-F (11-13) are called terpenyl-taurines phorbasins, due to the incorporation of taurine amine moiety in their structure. Biosynthetically, phorbasins B-G (9-14) (Fig. 4) are mostly originated from a common pathway involving formation of monocarboxylic diterpene, phorbasin B (9). Acetylation of phorbasin B resulted in formation of phorbasin $C(\mathbf{1 0})$, while displacement of phorbasin B-hydroxyl group by hypotaurine or taurine yielding the terpenyl taurine compounds (11-13) (Fig. 4). ${ }^{14}$ All the above mentioned phorbasins showed cytotoxic activity against various

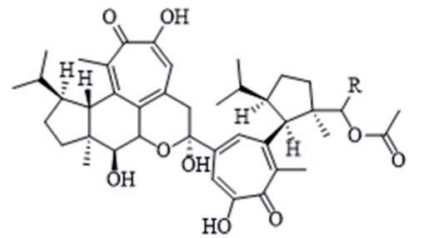

$36: \mathrm{R}=\mathrm{CHO}$

37: $\mathrm{R}=\mathrm{CHO}$

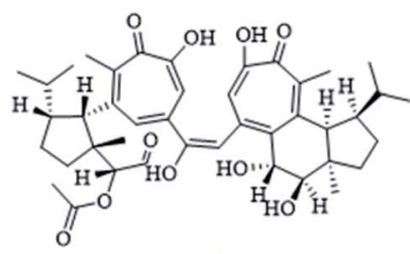

41

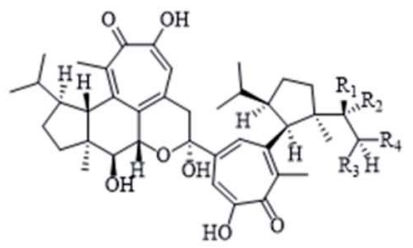

38: $\mathrm{R}_{1}=\mathrm{H}, \mathrm{R}_{2}=\mathrm{OH}, \mathrm{R}_{3}=\mathrm{OCH}_{3}, \mathrm{R}_{4}=\mathrm{NHCOCH}_{3}$

39: $\mathrm{R}_{1}=\mathrm{H}, \mathrm{R}_{2}=\mathrm{OH}, \mathrm{R}_{3}=\mathrm{OH}, \mathrm{R}_{4}=\mathrm{NHCOCH}_{3}$

40: $\mathrm{R}_{1}+\mathrm{R}_{2}=\mathrm{O}, \mathrm{R}_{3}=\mathrm{H}, \mathrm{R}_{4}=\mathrm{NH}\left(\mathrm{CH}_{2}\right)_{2} \mathrm{SO}_{3} \mathrm{H}$

Fig. 7 Structure of compounds 36-41. 


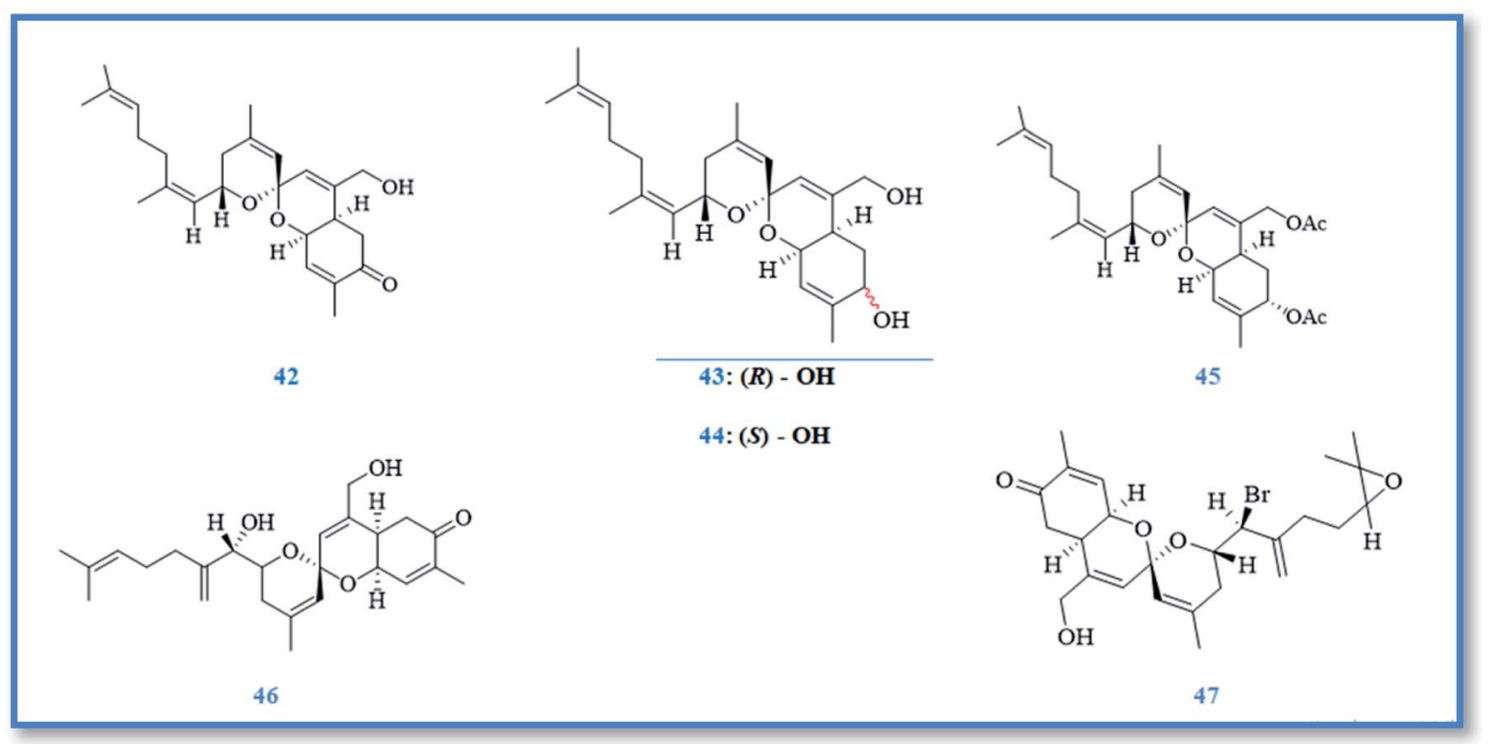

Fig. 8 Structure of compounds 42-47.

cell lines such as, lung carcinoma (A549), colorectal carcinoma (HT29), and malignant melanoma of skin (MM96L). It is noteworthy that phorbasin I displayed the most cytotoxic activity against lung and colorectal carcinoma with $\mathrm{GI}_{50}$ value (concentration required for $50 \%$ inhibition of growth) of $2.5 \mu \mathrm{M}$ for both cell lines, however the maximum cytotoxic activity against malignant melanoma cell line exhibited by phorbasin $\mathrm{H}$ with $\mathrm{GI}_{50}$ value of $0.8 \mu \mathrm{M}$. Phorbasins $\mathrm{B}, \mathrm{C}, \mathrm{G}, \mathrm{H}$, I were more selective towards cancer cell lines versus normal cell line. ${ }^{15}$ In addition, only phorbasin $\mathrm{H}$ inhibited $C$. albicans virulence factors. ${ }^{16}$ On the other hand, gagunins are large category of polyoxygenated diterpenes which identified as gagunins $\mathrm{A}-\mathrm{Q}$ (19-35) (Fig. 5 \& 6). ${ }^{17,18}$ Gagunins showed cytotoxic activity against human leukemia (K-562) cell line with varying activities $\left(\mathrm{LC}_{50}=0.049-86.395 \mu \mathrm{M}\right)$. Whereas, gagunin $\mathrm{E}(23)$ exhibited the most potent activity with $\mathrm{LC}_{50}$ value of $0.049 \mu \mathrm{M} .^{18,19}$ As well as gagunin D (22) showed anti-melanogenic activity and it was reported as natural skin-whitening agent for treatment of melanogenesis. ${ }^{20,21}$

Additionally, tetraterpenoidal compounds isolated from the Korean marine sponge Phorbas gukhulensis were considered to be pseudo dimers of gagunins named gukulenins A-F (36-41) (Fig. 7) and exhibited significant cytotoxic activity against different cell lines with varying $\mathrm{IC}_{50}$ values. Upon measuring the in vitro cytotoxic activity of gukulenins A and B by using MTT assay against pharynx cancer (FaDu), colon cancer (HCT-116), renal cancer (SN12C) and stomach cancer (MKN45) cell lines, gukulenin A showed the highest cytotoxic activity with $\mathrm{IC}_{50}$ value of 57, 62, 92 and $130 \mathrm{nM}$, respectively. ${ }^{22}$ Gukulenins A and C-F compounds were tested for their cytotoxic activity against leukemia (K562) and lung carcinoma (A549) cell lines.Gukulenin $\mathrm{F}$ exhibited the highest activity against leukemia with $\mathrm{IC}_{50}$ value of $0.04 \mu \mathrm{M}$, while gukulenin $\mathrm{C}$ was the highest cytotoxic compound against lung carcinoma (A549) compared to doxorubicin with $\mathrm{LC}_{50}$ value of $0.10 \mu \mathrm{M}^{23}$ Additionally, the cytotoxic activity of gukulenin A was examined by using in vitro assay against ovarian cancer (A2780, SKOV3, OVCAR-3, and TOV-21G) cell lines together with in vivo investigation by using an ovarian cancer mouse model generated by injecting A2780 cells. It was found that gukulenin A inhibited tumor growth in A2780-bearing mice as well as, it displayed potent cytotoxic activity against the four ovarian cancer cell lines with $\mathrm{IC}_{50}$ values of $0.03-0.36 \mu \mathrm{M}^{24}$

On the other hand, sesterterpenoids are also represented as small category of phorbaketal compounds and were isolated from Phorbas sp., including phorbaketals A-C (42-44) ${ }^{25}$ phorbaketal derivative (45), ${ }^{26}$ phorbaketals $\mathrm{L}$ (46) and $\mathrm{N}(47)$ (Fig. 8) ${ }^{27}$ Phorbaketals showed various cytotoxic potential against different cell lines as colorectal carcinoma (HT-29), hepatocellular carcinoma (HepG2), lung cancer (A549), pancreatic cancer (panc-1) and renal cancer (A498 and ACHN) with $\mathrm{IC}_{50}$ values of $11.4-50 \mu \mathrm{M} .{ }^{25}$ Phorbaketal $\mathrm{N}$ revealed higher cytotoxic activity against pancreatic cancer cell line with $\mathrm{IC}_{50}$ value of 11. $4 \mu \mathrm{M}$ compared to fluorouracil, the positive control. ${ }^{27}$ Moreover, phorbaketal A revealed potent antiinflammatory activity via inhibition the release of nitric oxide (NO). ${ }^{28}$ Besides, anti-HIV sesterterpenoids were isolated from phorbas sp., namely alotaketals C (48) and D (49), ansellone A (50), and anvilone A (51) (Fig. 9). ${ }^{29}$ These sesterterpenoidal compounds were reported to activate latent proviral HIV-1gene expression in a latent HIV-1 reservoirs cell line model, whereas the highest activity was displayed by alotaketal $\mathrm{C}$ as it was more potent than the control drug prostratin at the same concentration. ${ }^{30}$ Additionally, alotaketal $\mathrm{C}$ and ansellone A were also found to activate the intracellular second messenger cAMP signaling pathway. ${ }^{31,32}$ Biosynthetically, phorin A (a compound isolated from other marine sponge named, Monanchora sp.) was considered to be a precursor of phorbaketals and alotaketals biogenesis. The biosynthesis of this tricyclic spiroketal skeleton was proposed to begin from geranyl farnesyl pyrophosphate. 


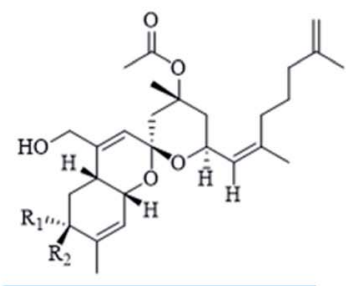

48: $R_{1}=R_{2}=0$

49: $\mathrm{R}_{1}=\mathrm{OAc}, \mathrm{R}_{2}=\mathrm{H}$

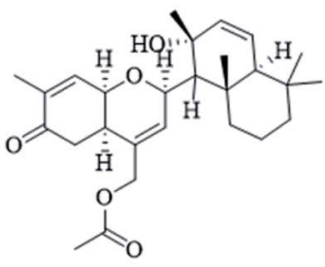

50

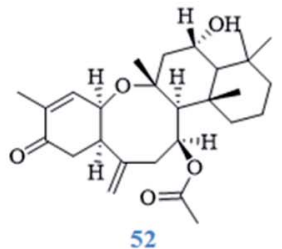<smiles>CC(=O)O[C@H]1C[C@@]2(C)CC([C@H]3CC=C(C)C(=O)C3)=CC(O)C2[C@@H]2CCCC(C)(C)[C@H]12</smiles>

51

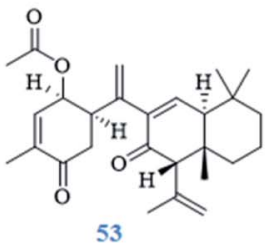

Fig. 9 Structure of compounds $48-53$

After the dissociation of pyrophosphate, an allylic cation is formed and attacked by olefin to form alotane skeleton. Then oxidation of alotane skeleton resulted in formation of phorin A, the key compound, which by further oxidation and cyclization lead to formation of the parent compounds, alotaketal A and phorbaketal A. ${ }^{33}$ phorbaketal A demonstrated dual action on mesenchymal stem cells differentiation, as it stimulated osteoblast differentiation which was considered to be a novel strategy in treatment of osteoporosis. ${ }^{34}$ Additionally, it inhibited adipogenic differentiation that can be a developed method for treatment of obesity. ${ }^{35}$ Other anti-inflammatory sesterterpenoids were also isolated from Phorbas sp., namely ansellone B (52) and phorbasone A acetate (53) (Fig. 9). They showed a potent inhibition of nitric oxide (NO) production in RAW
264.7 LPS-activated mouse macrophage cells with $\mathrm{IC}_{50}$ values of 4.5 and $2.8 \mu \mathrm{M}$, respectively. Particularly, ansellone B showed selectivity index of 3.8 , which indicates its anti-inflammatory activity without cytotoxicity. ${ }^{36}$

Additionally, the phytochemical investigation of the Antarctic marine sponge $P$. areolatus resulted in the isolation of suberitane sesterterpenoids namely, isosuberitenone B (54), 19episuberitenone B (55), suberitenone B (56), isoxaspirosuberitenone (57) and oxaspirosuberitenone (58) (Fig. 10). All of these compounds exhibited cytotoxic activity against different cell lines whereas, only isosuberitenone B and 19-episuberitenone B exerted high potent cytotoxic activity against A549, HepG2, HT-29, and MCF-7 cell lines, while the other compounds showed less significant activity against these

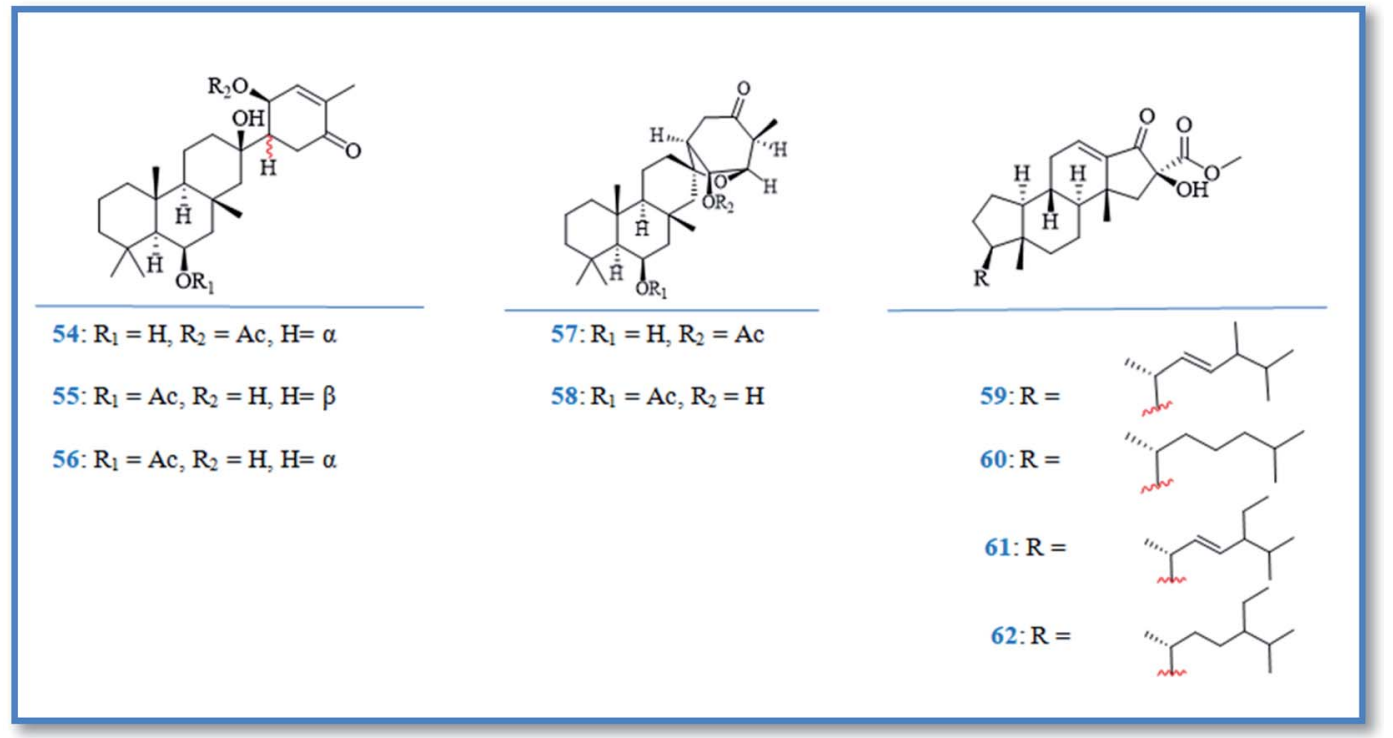

Fig. 10 Structure of compounds 54-62. 


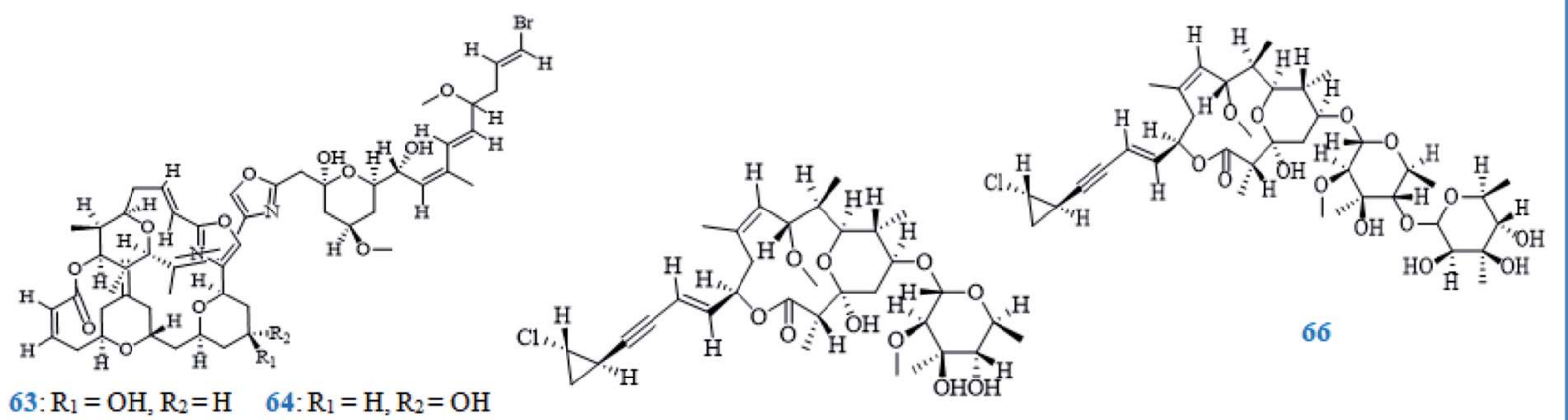

65

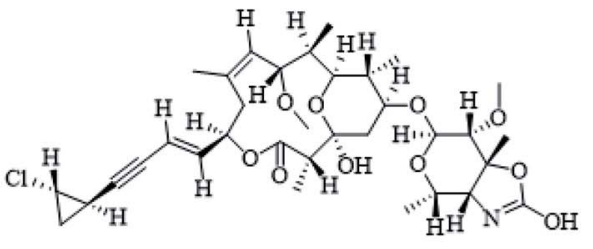

67

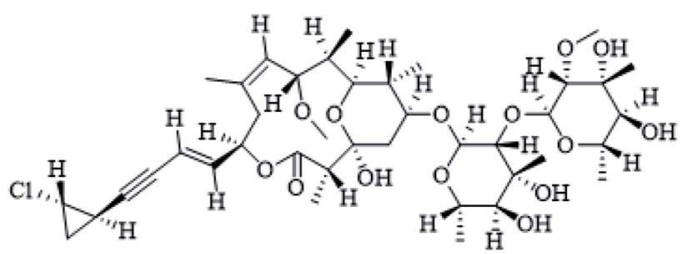

68

Fig. 11 Structure of compounds 63-68.

cell lines with $\mathrm{IC}_{50}$ values of 5-25 $\mu \mathrm{M}$. Only oxaspirosuberitenone showed antimicrobial activity against the methicillin resistant Staphylococcus aureus (MRSA). ${ }^{37}$

As a part of ongoing search for bioactive metabolites from marine origin, steroids, macrolides and macrolide glycosides were identified. Whereas, phorbasterones A-D (59-62) (Fig. 10) are steroidal compounds isolated from $P$. amaranthus sponge and showed cytotoxic activity against colon cancer (HCT-116) cell line with $\mathrm{IC}_{50}$ values of $1-3 \mu \mathrm{g} \mathrm{mL}{ }^{-1}$ in the MTS assay. ${ }^{38}$ Besides, the cytostatic macrolides phorboxazoles A (63) and B (64) (Fig. 11) isolated from Phorbas sp. displayed inhibitory activity against Saccharomyces carlsbergensis and antifungal activity against $C$. albicans, whereas phorboxazole A exhibited more potent antifungal potential at the concentration of 0.1 $\mu \mathrm{g} .{ }^{39}$ In addition, the macrolide glycosides phorbasides A (65) and C-E (66-68) (Fig. 11) were isolated from Phorbas sp. and showed cytotoxic activity against human colon cancer (HCT116) cell line. The most potent cytotoxic activity against colon cancer cell line was exerted by phorbaside $\mathrm{C}$ with an $\mathrm{IC}_{50}$ value of $2.0 \mu \mathrm{M}$; however phorbasides A, D and $\mathrm{E}$ were less active with $\mathrm{IC}_{50}$ values of $30,61.9$ and $10.2 \mu \mathrm{M}$, respectively. ${ }^{40}$

Other antioxidant compounds were identified from Mediterranean marine sponge Phorbas topsenti including, astaxanthin (69), adonirubin (70), taurine (71), and taurobetain (72) (Fig. 12). These compounds exhibited antioxidant activity in oxygen radical absorbance capacity (ORAC) assay with ORAC<smiles>[Z2]C1CC(C)(C)C(/C=C/C(C)=C/C=C/C(C)=C/C=C/C=C/C(C)=C/C=C(C)/C=C/C2=C(C)C(=O)C([Z])CC2(C)C)=C(C)C1=O</smiles><smiles>CC(CS(=O)(=O)O)N(C)C</smiles>

72<smiles>NCCS(=O)(=O)O</smiles>

71<smiles>O=Cc1ccc(O)cc1</smiles>

73

Fig. 12 Structure of compounds 69-73. 


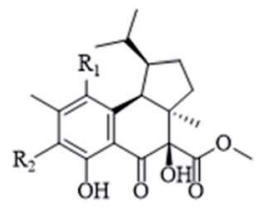

$74: \mathrm{R}_{1}=\mathrm{H}, \mathrm{R}_{2}=\mathrm{Br}$

$78: R_{1}=R_{2}=H$

$79: \mathrm{R}_{1}=\mathrm{R}_{2}=\mathrm{Br}$

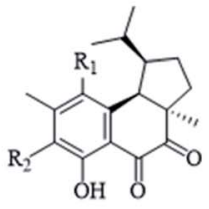

$75: \mathrm{R}_{1}=\mathrm{H}, \mathrm{R}_{2}=\mathrm{Br}$

$80: R_{1}=R_{2}=B r$

$81: R_{1}=R_{2}=H$
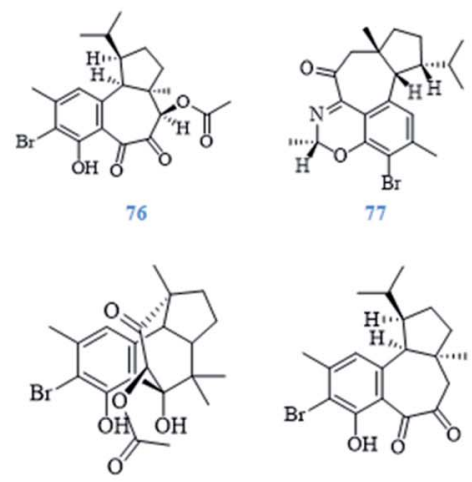

Fig. 13 Structure of compounds 74-83.

values of $0.22,0.024,0.083$ and 0.019 , respectively. ${ }^{12}$ As well as, the $p$-hydroxybenzaldehyde (73) (Fig. 12) isolated from marine sponge Phorbas paupertas exhibited slight antimicrobial activity against $S$. aureus bacteria, in addition to two yeasts $C$. albicans and C. tropicalis. ${ }^{10}$

\subsection{Genus Hamigera Gray, 1867}

Hamigera is a poecilosclerid sponge found predominately around northern New Zealand. ${ }^{41}$ This genus has a synonym namely, Cribrella and includes numerous species. Only, three of them were reported for their biological active compounds. ${ }^{5,42} \mathrm{H}$. tarangaensis, an orange-red to bright yellow sponge, is found mainly around northern New Zealand. ${ }^{41}$ Its phytochemical investigation resulted in identification of about thirty-eight hamigeran compounds, which are large class of bioactive diterpenes with variable grade of cyclization and bromination. This class includes; hamigeran A (74), B (75), C (76), and D (77) (Fig. 13). ${ }^{43}$ Debromohamigeran A $(\mathbf{7 8})^{43}$ and 4-bromohamigeran A $(79)^{44}$ are derivatives of hamigeran $\mathrm{A}$ and were also isolated from the same sponge. Hamigeran B derivatives are also represented as, 4-bromohamigeran $\mathrm{B}(\mathbf{8 0})^{43}$ and debromohamigeran B (81) $)^{44}$ (Fig. 13). Besides, hamigerans F-L (82-88) (Fig. 13 and 14) together with hamigerans M-Q (89-93) (Fig. 15) were isolated by Singh et al. from $H$. tarangaensis marine sponge. ${ }^{41}$ While the other hamigeran derivatives were identified as debromohamigeran I (94), debromohamigeran $\mathrm{J}^{44}$ (95), and 4bromohamigeran $\mathrm{K}(\mathbf{9 6})^{41}$ Hamigeran $\mathrm{L}$ derivatives were also identified as, hamigeran L 11-O-methyl ester $(\mathbf{9 7})^{41}$ and

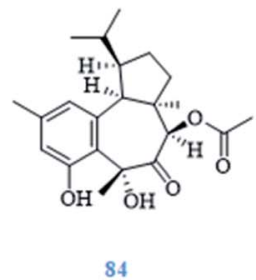

84

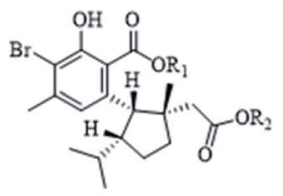

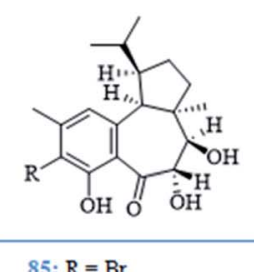

94: $\mathrm{R}=\mathrm{H}$

88: $\mathrm{R}_{1}=\mathrm{R}_{2}=\mathrm{H}$
97: $\mathrm{R}_{1}=\mathrm{R}_{2}=\mathrm{CH}_{3}$
98: $\mathrm{R}_{1}=\mathrm{CH}_{3}, \mathrm{R}_{2}=\mathrm{H}$

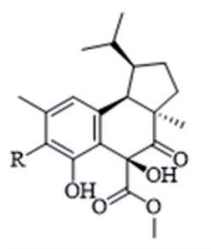

$86: \mathrm{R}=\mathrm{Br}$

$95: \mathrm{R}=\mathrm{H}$

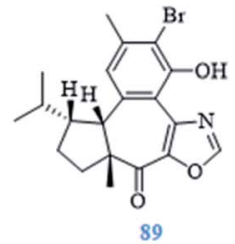

Fig. 14 Structure of compounds 84-89 and 94-99. 


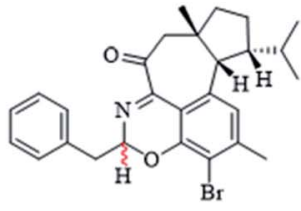

$90: \mathrm{H}=\alpha$

$100: H=\beta$

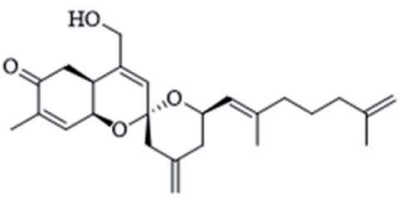

103

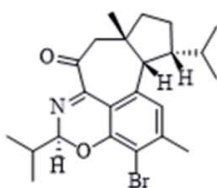

91

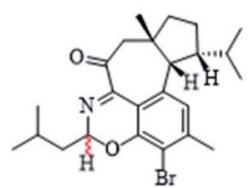

$92: H=\alpha$

$101: H=\beta$

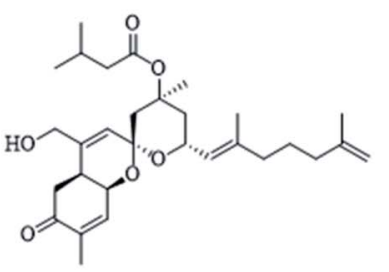

104

Fig. 15 Structure of compounds $90-93$ and 100-104.

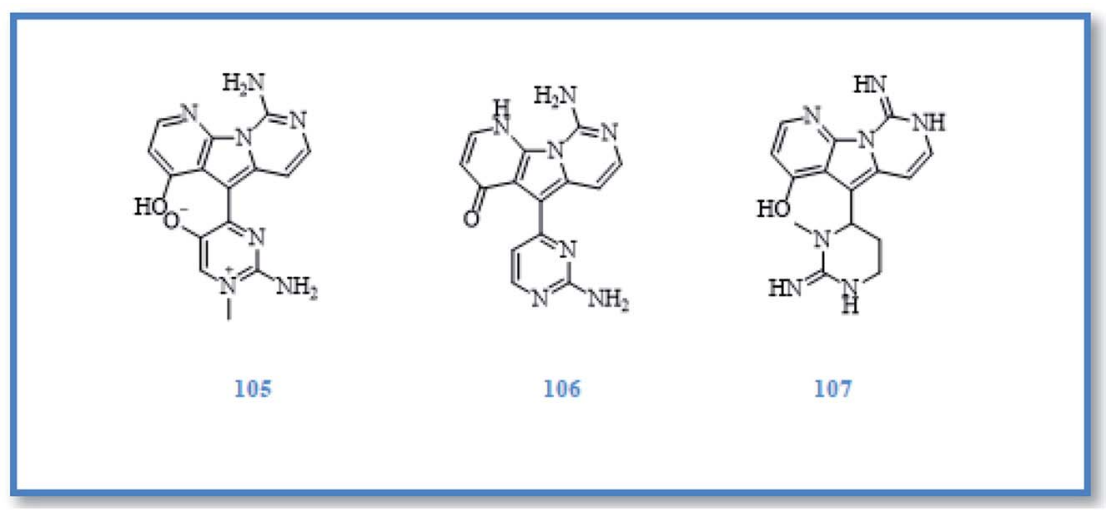

Fig. 16 Structure of compounds 105-107.

hamigeran L 12-O-methyl ester (98).$^{\mathbf{4 4}}$ Finally isomeric derivatives of hamigerans ${ }^{45}$ were later isolated as 10-epihamigeran $\mathrm{K}$ (99) (Fig. 14), 18-epihamigeran N (100), 18-epihamigeran P (101) and 19-epihamigeran $\mathrm{Q}(\mathbf{1 0 2}) .^{41}$

Most of hamigerans displayed interesting cytotoxic activity towards leukemia (HL-60) and (P-388) cell lines whereas, hamigeran $\mathrm{G}$ exerted the strongest in vitro cytotoxic activity in MTT assay against HL-60 cell line with $\mathrm{IC}_{50}$ value of $2.5 \mu \mathrm{M}$, while hamigerans B, F, M and 4-bromohamigeran $\mathrm{K}$ showed less significant cytotoxic activity on the same cell line with $\mathrm{IC}_{50}$ values of 3.4, 4.9, 6.9 and $5.6 \mu \mathrm{M}$, respectively. However, the other hamigerans exhibited moderate cytotoxic activity against HL-60 cell line with $\mathrm{IC}_{50}$ values ranging from 11.6-43 $\mu \mathrm{M}^{\mathbf{4 1 , 4 4 , 4 5}}$ Hamigeran $\mathrm{L}$ showed the lowest cytotoxic activity in the same assay. Regarding to (P-388) cell line, the most potent cytotoxic compound was hamigeran $\mathrm{D}$ with $\mathrm{IC}_{50}$ value of $8 \mu \mathrm{M}$, while hamigeran $\mathrm{B}, \mathrm{C}$ and 4-bromohamigeran $\mathrm{B}$ showed less cytotoxic activity with $\mathrm{IC}_{50}$ values of $13.5,16$ and $13.9 \mu \mathrm{M}$, respectively. ${ }^{43}$ Likewise, hamigeran A exhibited the lowest cytotoxic activity against (P-388) cell line out of all with $\mathrm{IC}_{50}$ value of $31.6 \mu \mathrm{M}$. In addition, hamigeran $\mathrm{B}$ exerted a very potent activity against both Herpes simplex and Polio viruses, as it showed 100\% inhibition with very low cytotoxicity at the concentration of 132 $\mu \mathrm{g}$. Upon examining the antimicrobial activity of hamigerans, only hamigeran $\mathrm{C}$ and hamigeran $\mathrm{D}$ showed activity against Gram-positive bacterium Bacillus subtilis with an inhibition zone of $3 \mathrm{~mm}$ using concentration of 96 and $150 \mu \mathrm{g}$, respectively. While, hamigerans B, C and D showed slight anti-fungal activity against Trichophyton mentagrophytes. ${ }^{43}$ Further studies revealed a captivating activity of hamigeran $\mathrm{G}$ against budding yeast Saccharomyces cerevisiae. However, yeast strain deficient in drug efflux pumping activity was used to maximize the effect of hamigeran $\mathrm{G}$ as long as with a homozygous diploid yeast strain with normal efflux pump activities, hamigeran $G$ selectively 


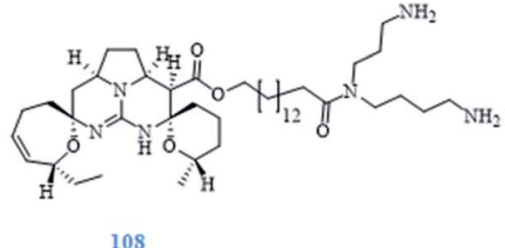

108<smiles>O=C1NC(=O)/C(=C/c2ccc(O)cc2)N1</smiles>

109

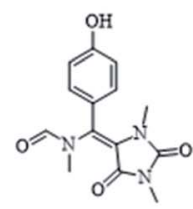

110

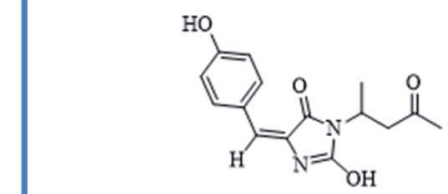

111

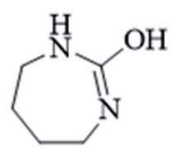

112

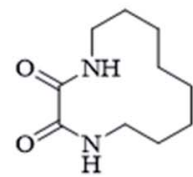

113

Fig. 17 Structure of compounds 108-113.

inhibited growth of both strains with $\mathrm{IC}_{50}$ values of 6.7 and 16.5 $\mu \mathrm{M}$, respectively. ${ }^{41}$

From biogenetic point of view, most hamigerans contain 56-6 or 5-7-6 fused tricarbocyclic rings, also known as A-B-C rings, and they can be divided into two carbon skeletons originating from geranyl geranyl pyrophosphate (GGPP). ${ }^{41}$ The main nucleus was proposed to be hamigerane which is a six membered nucleus (B ring) or as isohamigerane with seven membered nucleus (B ring) in the main skeleton. In case of hamigeran $\mathrm{F}$ additional ring exists; it resulted in formation of third skeleton named neo-hamigeran, whereas cleavage of ring B of the tricylic system leads to formation of 5-6 structure (A-C rings) which is the main skeleton of hamigeran $\mathrm{L} .{ }^{46}$ Moreover, the biogenetic origin of nitrogenous hamigerans is attributed to an amino acid source and hamigeran $\mathrm{G}$ is a precursor of the main skeleton of these nitrogenous compounds so, condensation of hamigeran $\mathrm{G}$ with different amino acids resulted in formation of different nitrogenous hamigerans (hamigerans $\mathrm{D}, \mathrm{M}, \mathrm{N}, \mathrm{O}, \mathrm{P}$ and $\mathrm{Q}){ }^{45,46}$

Two new sesterterpenoidal compounds had been isolated from marine sponge Hamigera sp. extract as a part of searching for bioactive natural products from this genus namely, alotaketal A (103) and alotaketal B (104) (Fig. 15). ${ }^{47}$ However, the intracellular second messenger cAMP is important in cell signaling pathway and compounds that can selectively modulate this signaling pathway attract the attention as a drug candidate. Alotaketals A and B were found to be activator of this signaling pathway by activation of cAMP with $\mathrm{EC}_{50}$ values of 18 and $240 \mathrm{nM}$, respectively. ${ }^{47}$ In addition, investigation of $H$. hamigera marine sponge resulted in isolation of p-hydroxy benzaldhyde $(73)^{42}$ which had been previously isolated from genus Phorbas.

\subsection{Genus Kirkpatrickia topsent, 1912}

Kirkpatrickia is a rare Antarctic sponge which includes three accepted species namely, $K$. tedania, $K$. variolosa and $K$.
Kirkpatrick. However, only $K$. variolosa (synonym Tedania variolosa) was reported for its biologically active compounds. ${ }^{5}$ It afforded variolins which are novel marine natural products with a pyrido $\left[3^{\prime}, 2^{\prime}: 4,5\right]$ pyrrolo[1,2-c] pyrimidine system $^{48}$ and include, variolin A (105), variolin B (106) and $N\left(3^{\prime}\right)$-methyltetrahydrovariolin B (107) (Fig. 16). ${ }^{49}$ Variolin B exerted a very potent cytotoxic activity against murine leukemia (P-338) cell line with $\mathrm{IC}_{50}$ value of $0.716 \mu \mathrm{M}$. Moreover, it was found to be activator of apoptosis and exhibited cytotoxic activity against different human cancer cell lines as ovarian cancer (A-2780), colon cancer (HCT-116), and colorectal carcinoma (LoVo) cell lines with varying $\mathrm{GI}_{50}$ values of $50-100 \mathrm{nM},{ }^{50,51}$ including those which overexpressed by p-glycoprotein (pgp) and the cell efflux pump responsible for cancerous cells resistance to multiple chemotherapeutic agents. ${ }^{52,53}$ However, N (3')-methyltetrahydrovariolin B showed cytotoxic activity against human colon cancer cell line (HCT 116) with $\mathrm{IC}_{50}$ value of $1.542 \mu \mathrm{M}$, variolin A showed only aweak in vitro cytotoxic activity against (P388) cell line with $\mathrm{IC}_{50}$ value of $11.753 \mu \mathrm{M} .{ }^{54}$ Moreover, variolin B showed a potent activity against Herpes simplex virus type I and weak activity against polio virus type $\mathrm{I}^{, 55}$ while $N\left(3^{\prime}\right)$-methyltetrahydrovariolin B exerted antimicrobial activity against Saccharomyces cerevisiae..$^{54}$

\subsection{Genus Hemimycale Burton, 1934}

In the course of an unending search for the novel bioactive secondary metabolites, the red sea marine sponges from genus Hemimycale were investigated and afforded different bioactive natural products. Alkaloids were the major isolated compounds from this genus. Ptilomycaline A (108) (Fig. 17), a novel guanidine alkaloid, was the first compound isolated from Hemimycale sp. and showed cytotoxic activity against leukemia P-388 cell line with $\mathrm{IC}_{50}$ value of $0.127 \mu \mathrm{M}$. It also displayed antifungal activity against $C$. albicans with MIC value of $1.019 \mu \mathrm{M}$ and antiviral potential activity against $\mathrm{HSV}$ at concentration of 0.255 $\mu \mathrm{M} .^{56,57}$ Later on, (Z)-5-(4-hydroxybenzylidene)-hydantoin (109) 
(phenylmethylene hydantoin) (Fig. 17) was isolated from $H$. arabica which is considered a potent prostate cancer migration inhibitor as it exhibited significant anti-invasive and cytotoxic activity against prostate cancer (PC-3M) cell line with $\mathrm{EC}_{50}$ value of $150 \mu \mathrm{M} \cdot{ }^{58-60}$ Also, it exhibited cytotoxic activity against human cervical carcinoma (HeLa) cell line with IC $_{50}$ value of 138.596 $\mu \mathrm{M}$ and antimicrobial activity against both E. coli and C. albicans. ${ }^{61}$ Further investigation of $H$. arabica resulted in isolation of additional two alkaloids namely, hemimycalin A (110) and hemimycalin B (111) (Fig. 17), which exhibited variable antimicrobial activity against $E$. coli and C. albicans. ${ }^{61}$ In addition to the previously isolated alkaloids, two cyclic urea derivatives were identified in $H$. arabica namely, [1,3]-diazepan-2-one (112) and $(S)$-1,4-diaza-cyclododecane-2,3-dion (113) (Fig. 17) which displayed hypoglycemic activity with $\mathrm{EC}_{50}$ value of 60 and below $1.29 \mu \mathrm{M}$, respectively. However, both cyclic urea compounds exhibited significant cytotoxic activity against hepatocellular carcinoma (HepG2) cell line and colon cancer (HCT-116) cell line. [1,3]-Diazepan-2-one was high potential against both cell lines and exerted no cytotoxicity to the used model of normal cell line which suggest its importance as a promising selective anticancer agent. $^{62}$

\section{Conclusion and future perspectives}

Family Hymedesmiidae is one of the largest marine sponge families and was found to be an exceptional reservoir rich of potentially active secondary metabolites. In such review, 113 bioactive compounds have been reported along with their unique structures, biological sources and biological activities established on the data gathered from the Marin Lit database and accessible literature. It was clear that the genera Phorbas,

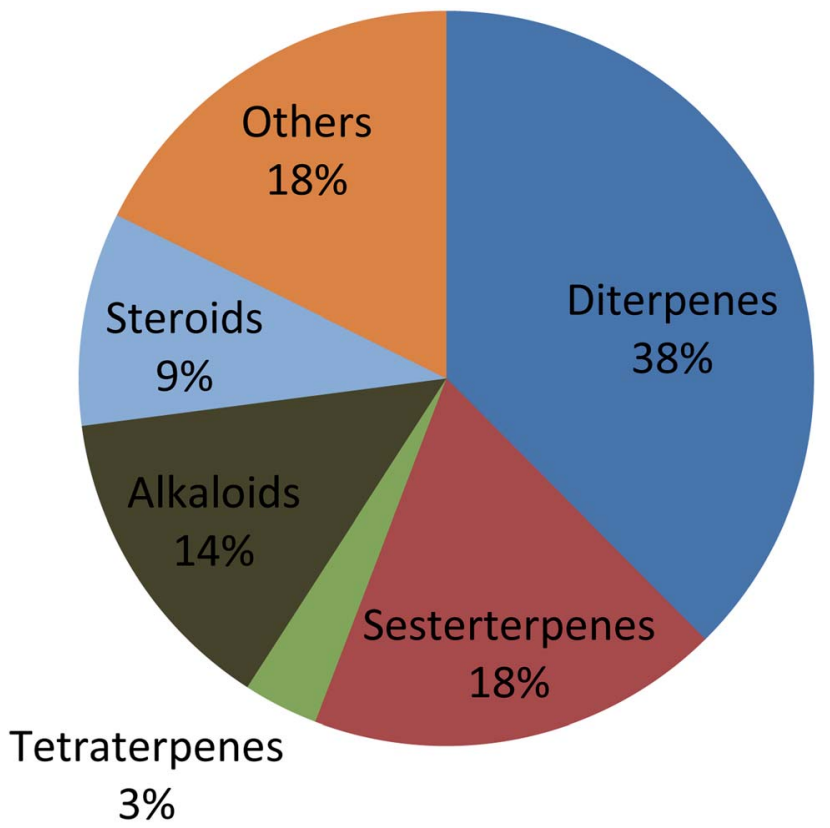

Fig. 18 Percentage of different classes of compounds distributed in family Hymedesmiidae.

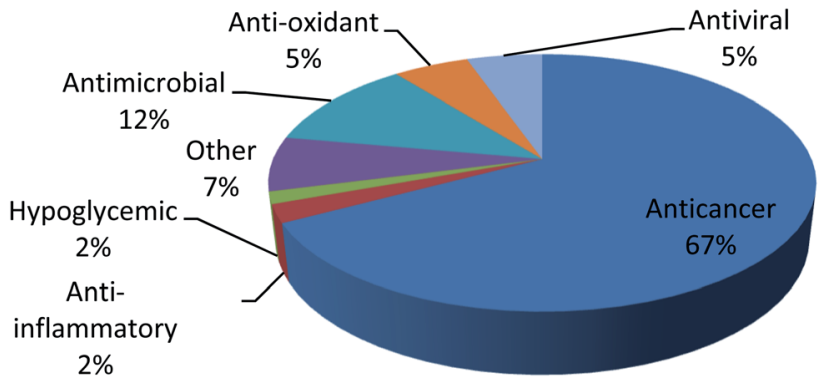

Fig. 19 Bioactivity profile of the compounds isolated from family Hymedesmiidae.

Hamigera, Kirkpatrickia and Hemimycale were the most investigated ones and were able to produce bioactive secondary metabolites such as diterpenes, sesterterpenes, tetraterpenes, alkaloids and other compounds (Fig. 18). Most of the secondary metabolites from this family exhibited unique skeletons and marvelous biological activities which have received more attention as potential drugs such as, anticancer, antiinflammatory, antiviral, antioxidant and antimicrobial agents. Several compounds were found to exert antitumor activity against wide range of cell lines like, hepatocellular carcinoma, lung cancer, prostate cancer, leukemia, pharynx cancer, colon cancer, and stomach cancer (Fig. 19). Various compounds exhibited $\mathrm{IC}_{50}$ value below $1 \mu \mathrm{M}$ such as, gagunin compounds and variolin B against leukemia cell line, while gukulenins A and B displayed cytotoxicity against pharynx cancer cell line as well as colon, renal and stomach cancer cell lines. So these compounds have a great potential to be applied in the discovery of new anticancer drugs. Despite this potent antitumor potential of most compounds, only gukulenin A, variolin B, and phenyl methylene hydantion were extensively studied in in vivo assays against ovarian, leukemia, and prostate cancer cell lines, respectively. Moreover other compounds provided a new strategy for treatment of different diseases as phorbaketal A in treatment of osteoporosis and obesity, gagunin D in treatment of melanogenesis, alotaketal $\mathrm{C}$ in activation of latent proviral HIV-1 gene expression which aids in complete eradication of virus in HIV-1 infected persons and ansellone $B$ that was considered to be a new compound for treatment of inflammatory disease.

Nevertheless, some considerable gaps in studying family Hymedesmiidae have been revealed from the analysis of the reviewed data. Firstly, some genera like Acanthancora, Pseudohalichondria, Plocamionida, Spanioplon, Myxodoryx and Hymedesmia have paid less attention regarding their chemical and biological investigation. Additionally, structure-activity relationships studies for the isolated bioactive metabolites from the family Hymedesmiidae should be investigated to illuminate their prospective mechanisms of actions as anticancer agents. Molecular docking simulation of the identified isolated cytotoxic compounds will be of prominent value to discover the mechanism of binding with the proper targets and in designing new anticancer compounds. Moreover, synthetic analogues of the isolated bioactive compounds of the family Hymedesmiidae 
should be processed based on enhancing their efficacy and safety. Finally, preclinical and clinical studies should be performed on the isolated compounds, in particular the cytotoxic metabolites. As consequence, such sponges should receive more efforts to transform them into market products as they provide a precious source of novel bioactive metabolites with valuable biological activities.

\section{Conflicts of interest}

The authors declare no conflict of interest.

\section{Acknowledgements}

This publication was funded by Minia University.

\section{References}

1 B. Joseph and S. Sujatha, J. Nat. Prod., 2011, 4, 12.

2 R. Abou El-Ezz, A. Ibrahim, E. Habib, H. Kamel, M. Afifi, H. Hassanean and S. Ahmed, Int. J. Pharm. Sci. Res., 2017, 8, 940.

3 A. F. Wali, S. Majid, S. Rasool, S. B. Shehada, S. K. Abdulkareem, A. Firdous, S. Beigh, S. Shakeel, S. Mushtaq and I. Akbar, Saudi Pharm. J., 2019, 27, 767-777. 4 M. J. Uriz, L. Garate and G. Agell, PeerJ, 2017, 5, e2958.

5 R. W. Van Soest, in Systema Porifera, Springer, 2002, pp. 575593.

6 A. Casapullo, E. Finamore, L. Minale and F. Zollo, Tetrahedron Lett., 1993, 34, 6297-6300.

7 A. Casapullo, L. Minale, F. Zollo and J. Lavayre, J. Nat. Prod., 1994, 57, 1227-1233.

8 S. Bastos Lemos Silva, M. A. Beniddir, J. F. Gallard, E. Poupon, O. P. Thomas and L. Evanno, Eur. J. Org. Chem., 2019, 2019, 5515-5518.

9 B. B. Snider, F. Song and B. M. Foxman, J. Org. Chem., 2000, 65, 793-800.

10 N. Bouaicha, P. Amade, D. Puel and C. Roussakis, J. Nat. Prod., 1994, 57, 1455-1457.

11 N. Loaëc, E. Attanasio, B. Villiers, E. Durieu, T. Tahtouh, M. Cam, R. A. Davis, A. Alencar, M. Roué and M.-L. Bourguet-Kondracki, Mar. Drugs, 2017, 15, 316.

12 T. D. Nguyen, X. C. Nguyen, A. Longeon, A. Keryhuel, M. H. Le, Y. H. Kim and M.-L. Bourguet-Kondracki, Tetrahedron, 2012, 68, 9256-9259.

13 M. McNally and R. J. Capon, J. Nat. Prod., 2001, 64, 645-647. 14 H. Zhang and R. J. Capon, Org. Lett., 2008, 10, 1959-1962.

15 H. Zhang, J. M. Major, R. J. Lewis and R. J. Capon, Org. Biomol. Chem., 2008, 6, 3811-3815.

16 S.-H. Lee, J.-e. Jeon, C.-H. Ahn, S.-C. Chung, J. Shin and K.-B. Oh, Appl. Microbiol. Biotechnol., 2013, 97, 3141-3148.

17 J.-R. Rho, H.-S. Lee, C. J. Sim and J. Shin, Tetrahedron, 2002, 58, 9585-9591.

18 K. H. Jang, J.-e. Jeon, S. Ryu, H.-S. Lee, K.-B. Oh and J. Shin, J. Nat. Prod., 2008, 71, 1701-1707.

19 K. E. Kim, Y. Sakazaki and B. M. Stoltz, Tetrahedron, 2019, 130755.
20 H. Y. Lee, E. J. Jang, S. Y. Bae, J.-e. Jeon, H. J. Park, J. Shin and S. K. Lee, Mar. Drugs, 2016, 14, 212.

21 W. Qian, W. Liu, D. Zhu, Y. Cao, A. Tang, G. Gong and H. Su, Exp. Ther. Med., 2020, 20, 173-185.

22 S. Y. Park, H. Choi, H. Hwang, H. Kang and J.-R. Rho, J. Nat. Prod., 2010, 73, 734-737.

23 J.-e. Jeon, L. Liao, H. Kim, C. J. Sim, D.-C. Oh, K.-B. Oh and J. Shin, J. Nat. Prod., 2013, 76, 1679-1685.

24 J.-H. Ahn, J.-H. Woo, J.-R. Rho and J.-H. Choi, Mar. Drugs, 2019, 17, 126.

25 J.-R. Rho, B. S. Hwang, C. J. Sim, S. Joung, H.-Y. Lee and H.-J. Kim, Org. Lett., 2009, 11, 5590-5593.

26 B. S. Hwang, C. Yang and J.-R. Rho, J. Korean Soc. Magn. Reson. Med., 2011, 15, 128-136.

27 Y. Lee, W. Wang, H. Kim, A. G. Giri, D. H. Won, D. Hahn, K. R. Baek, J. Lee, I. Yang and H. Choi, Bioorg. Med. Chem. Lett., 2014, 24, 4095-4098.

28 Y.-J. Seo, K.-T. Lee, J.-R. Rho and J.-H. Choi, Mar. Drugs, 2015, 13, 7005-7019.

29 M. Wang, I. Tietjen, M. Chen, D. E. Williams, J. Daoust, M. A. Brockman and R. J. Andersen, J. Org. Chem., 2016, 81, 11324-11334.

30 R. J. Andersen, F. Ntie-Kang and I. Tietjen, Antiviral Res., 2018, 158, 63-77.

31 J. Daoust, M. Chen, M. Wang, D. E. Williams, M. A. G. Chavez, Y. A. Wang, C. E. Merchant, A. Fontana, T. J. Kieffer and R. J. Andersen, J. Org. Chem., 2013, 78, 8267-8273.

32 J. Daoust, A. Fontana, C. E. Merchant, N. J. de Voogd, B. O. Patrick, T. J. Kieffer and R. J. Andersen, Org. Lett., 2010, 12, 3208-3211.

33 H. Yao, N. Zhou, Z. Zhang, W. Guan, H. Wang and H. Cheng, Tetrahedron Lett., 2020, 61, 151480.

34 M. R. Byun, A. R. Kim, J.-H. Hwang, M. K. Sung, Y. K. Lee, B. S. Hwang, J.-R. Rho, E. S. Hwang and J.-H. Hong, FEBS Lett., 2012, 586, 1086-1092.

35 M. R. Byun, C. H. Lee, J.-H. Hwang, A. R. Kim, S. A. Moon, M. K. Sung, J.-R. Roh, E. S. Hwang and J.-H. Hong, Eur. J. Pharmacol., 2013, 718, 181-187.

36 W. Wang, Y. Lee, T. G. Lee, B. Mun, A. G. Giri, J. Lee, H. Kim, D. Hahn, I. Yang and J. Chin, Org. Lett., 2012, 14, 4486-4489.

37 H. Solanki, C. Angulo-Preckler, K. Calabro, N. Kaur, P. Lasserre, B. Cautain, M. de la Cruz, F. Reyes, C. Avila and O. P. Thomas, Tetrahedron Lett., 2018, 59, 3353-3356.

38 M. N. Masuno, J. R. Pawlik and T. F. Molinski, J. Nat. Prod., 2004, 67, 731-733.

39 P. A. Searle and T. F. Molinski, J. Am. Chem. Soc., 1995, 117, 8126-8131.

40 J. B. MacMillan, G. Xiong-Zhou, C. K. Skepper and T. F. Molinski, J. Org. Chem., 2008, 73, 3699-3706.

41 A. J. Singh, J. D. Dattelbaum, J. J. Field, Z. Smart, E. F. Woolly, J. M. Barber, R. Heathcott, J. H. Miller and P. T. Northcote, Org. Biomol. Chem., 2013, 11, 8041-8051.

42 W. H. Hassan, Z. I. El-Sayed and P. Proksch, Biosci., Biotechnol. Res. Asia, 2007, 4, 351-358.

43 K. D. Wellington, R. C. Cambie, P. S. Rutledge and P. R. Bergquist, J. Nat. Prod., 2000, 63, 79-85. 
44 E. F. Woolly, A. J. Singh, E. R. Russell, J. H. Miller and P. T. Northcote, J. Nat. Prod., 2018, 81, 387-393.

45 J. D. Dattelbaum, A. J. Singh, J. J. Field, J. H. Miller and P. T. Northcote, J. Org. Chem., 2015, 80, 304-312.

46 X. Li, D. Xue, C. Wang and S. Gao, Angew. Chem., 2016, 128, 10096-10100.

47 R. Forestieri, C. E. Merchant, N. J. de Voogd, T. Matainaho, T. J. Kieffer and R. J. Andersen, Org. Lett., 2009, 11, 51665169.

48 P. Molina, P. M. Fresneda and S. Delgado, J. Org. Chem., 2003, 68, 489-499.

49 P. M. Pauletti, L. S. Cintra, C. G. Braguine, W. R. Cunha and A. H. Januário, Mar. Drugs, 2010, 8, 1526-1549.

50 P. M. Fresneda, S. Delgado, A. Francesch, I. Manzanares, C. Cuevas and P. Molina, J. Med. Chem., 2006, 49, 1217-1221.

51 M. Simone, E. Erba, G. Damia, F. Vikhanskaya, A. M. Di Francesco, R. Riccardi, C. Bailly, C. Cuevas, J. M. F. SousaFaro and M. D'Incalci, Eur. J. Cancer, 2005, 41, 2366-2377.

52 C. Imperatore, A. Aiello, F. D'Aniello, M. Senese and M. Menna, Molecules, 2014, 19, 20391-20423.

53 S. R. Walker, E. J. Carter, B. C. Huff and J. C. Morris, Chem. Rev., 2009, 109, 3080-3098.
54 G. Trimurtulu, D. J. Faulkner, N. B. Perry, L. Ettouati, M. Litaudon, J. W. Blunt, M. H. Munro and G. B. Jameson, Tetrahedron, 1994, 50, 3993-4000.

55 N. B. Perry, L. Ettouati, M. Litaudon, J. W. Blunt, M. H. Munro, S. Parkin and H. Hope, Tetrahedron, 1994, 50, 3987-3992.

56 Y. Kashman, S. Hirsh, O. J. McConnell, I. Ohtani, T. Kusumi and H. Kakisawa, J. Am. Chem. Soc., 1989, 111, 8925-8926.

57 I. Ohtani, T. Kusumi, H. Kakisawa, Y. Kashman and S. Hirsh, J. Am. Chem. Soc., 1992, 114, 8472-8479.

58 M. A. Khanfar, B. A. Asal, M. Mudit, A. Kaddoumi and K. A. El Sayed, Bioorg. Med. Chem., 2009, 17, 6032-6039.

59 G. V. Shah, A. Muralidharan, S. Thomas, M. Gokulgandhi, M. Mudit, M. Khanfar and K. El Sayed, Mol. Cancer Ther., 2009, 8, 509-520.

60 M. Mudit and K. A. El Sayed, Chem. Biodiversity, 2011, 8, 1470-1485.

61 D. T. Youssef, L. A. Shaala and K. Z. Alshali, Mar. Drugs, 2015, 13, 6609-6619.

62 M. Shaaban, A. Z. Hassan, M. M. Soltan and A. B. Abdelwahab, Med. Chem. Res., 2018, 27, 2079-2088. 